\title{
Liver fibrosis and altered matrix synthesis
}

\author{
Katrin Neubauer MD, Bernhard Saile MD, Giuliano Ramadori MD
}

\begin{abstract}
K Neubauer, B Saile, G Ramadori. Liver fibrosis and altered matrix synthesis. Can J Gastroenterol 2001;15(3):187-193. Liver fibrosis represents the uniform response of liver to toxic, infectious or metabolic agents. The process leading to liver fibrosis resembles the process of wound healing, including the three phases following tissue injury: inflammation, synthesis of collagenous and noncollagenous extracellular matrix components, and tissue remodelling (scar formation). While a single liver tissue injury can be followed by an almost complete restitution ad integrum, the persistence of the original damaging noxa results in tissue damage. During the establishment of liver fibrosis, the basement membrane components collagen type IV, entactin and laminin increase and form a basement membrane-like structure within the space of Disse. The number of endothelial fenestrae of the sinusoids decreases. These changes of the sinusoids are called 'capillarization' because the altered structure of the sinusoids resembles that of capillaries. At the cellular level, origin of liver fibrogenesis is initiated by the damage of hepatocytes, resulting in the recruitment of inflammatory cells and platelets, and activation of Kupffer cells, with subsequent release of cytokines and growth factors. The hepatic stellate cells seem to be the primary target cells for these inflammatory stimuli, because during fibrogenesis, they undergo an activation process to a myofibroblast-like cell, which represents the major matrixproducing cell. Based on this pathophysiological mechanism, therapeutic methods are developed to inhibit matrix synthesis or stimulate matrix degradation. A number of substances are currently being tested that either neutralize fibrogenic stimuli and prevent the activation of hepatic stellate cells, or directly modulate the matrix metabolism. However, until now, the elimination of the hepatotoxins has been the sole therapeutic concept available for the treatment of liver fibrogenesis in humans.
\end{abstract}

Key Words: Liver fibrosis; Matrix

\section{Fibrose du foie et altération de la synthèse matricielle}

RÉSUMÉ : La fibrose hépatique est une réaction uniforme du foie à des agents toxiques, infectieux ou métaboliques. Le processus aboutissant à la fibrose du foie ressemble au processus de cicatrisation en trois étapes à la suite d'une lésion tissulaire : l'inflammation, la synthèse de composants matriciels extracellulaires collagènes et non collagènes, et le remodelage du tissu (formation de la cicatrice). Même s'il ya reconstitution quasi complète du tissu hépatique à la suite d'une seule lésion du foie, la présence continue du facteur agressant initial entraîne des lésions tissulaires. Durant le processus de fibrose du foie, les composants collagènes de type IV de la membrane basale, l'entactine et la laminine, se développent et forment une structure semblable à celle de la membrane basale dans l'espace de Disse, tandis que le nombre de fenêtres endothéliales des sinusoïdes diminue. Ce dernier phénomène s'appelle « capillarisation » en raison de la transformation de la structure des sinusoïdes en une structure semblable à celle des capillaires. Au niveau cellulaire, la fibrogenèse du foie commence par l'atteinte des hépatocytes, qui se traduit par l'arrivée de cellules inflammatoires, de plaquettes et par l'activation des cellules de Kupffer, suivies de la libération de cytokines et de facteurs de croissance. Les cellules stellaires du foie semblent la principale cible de la réaction inflammatoire parce que, durant la fibrogenèse, elles subissent un processus de transformation en myofibroblastes, qui sont les plus grands producteurs de tissu matriciel. Aussi cherche-t-on à mettre au point des moyens thérapeutiques visant à inhiber la synthèse du tissu matriciel ou à en stimuler la dégradation. Certaines substances sont actuellement à l'essai : ou bien elles neutralisent l'activité fibrogène et empêchent l'activation des cellules stellaires du foie, ou bien elles modulent directement le métabolisme du tissu matriciel. Toutefois, le seul moyen dont on dispose actuellement pour traiter la fibrogenèse du foie est l'élimination des hépatotoxines.

This mini-review was prepared from a presentation made at the World Congress of Gastroenterology, Vienna, Austria, September 6 to 11, 1998

University of Göttingen, Department of Internal Medicine, Section of Gastroenterology and Endocrinology, Göttingen, Germany

Correspondence and reprints: Prof Dr G Ramadori, Department of Internal Medicine, Section of Gastroenterology and Endocrinology,

Georg-August - University Göttingen, Robert-Koch - Straße-40, D-37075 Göttingen, Germany. Telephone +49-551-396301,

fax +49-551-398596, e-mail Gramado@med.uni-goettingen.de

Received for publication July 14, 1999. Accepted July 19, 1999 
Iver cirrhosis is the result of a progressive increase in Lconnective tissue and a progressive reduction in functional active parenchyma; in other words, liver cirrhosis is a continuous wound healing process due to a continuous loss of vital parenchyma caused by different noxa (alcohol, viruses, metabolic disorders). This process leading to liver fibrosis includes the three phases following tissue injury: inflammation, synthesis and deposition of collagenous and noncollagenous extracellular matrix (ECM) components, and tissue remodelling (scar formation). Data from experimental animal models and observations of humans indicate that liver cirrhosis may be reversible when the damaging agent is withdrawn (eg, eradication of viruses).

\section{MECHANISMS OF ACUTE AND CHRONIC LIVER INJURY}

Inflammation: Inflammatory processes are characterized by migration of inflammatory cells into areas affected by various noxious agents. Migration induced by chemokines released at sites of injury is mediated by the interaction of adhesion molecules on migrating inflammatory cells and adhesion molecules on resident cells (mostly endothelial cells first and hepatic stellate cells [HSCs] afterwards) (1-4). Because noxious agents may only induce a 'disturbance' of hepatocytes and not necessarily induce cell death, hepatocellular necrosis may be a result of the interaction of 'disturbed' hepatocytes with recruited inflammatory cells (Figure 1). Following hepatocellular necrosis, there is an activation of repair mechanisms that either lead to a restitution ad integrum or, in the case of progressive disease, to the replacement of functional parenchyma by matrix (fibrogenesis). In different animal models of acute liver injury, it has been shown that the accumulation of inflammatory cells and the hepatic necrosis precede the proliferation and activation of HSCs as well as the formation of a 'provisional clot', which, therefore, are considered to constitute a part of the expected healing response to hepatocyte necrosis. On the other hand, HSCs may also be capable of contributing to the recruitment of inflammatory cells because it has been demonstrated that HSCs express chemokines (5-9). Furthermore, HSCs may be important for the transmigration of inflammatory cells by the synthesis of adhesion molecules as intercellular cell adhesion molecule-1, vascular cell adhesion molecules and neural cell adhesion molecules under conditions of inflammation $(2,10,11)$. Nevertheless, it is not definitively clear whether necroinflammation is always needed for the development of liver fibrosis. In fact, cirrhosis may develop in patients with hemochromatosis without inflammation. However, in most cases, following the persistence of noxious agents, necrosis and inflammation, changes occur that include the so called 'capillarization' of the sinusoids, the progressive deposition of ECM and the reduced matrix degradation, which finally leads to a scar formation.

'Capillarization' of the sinusoids: Changes of the hepatic sinusoids referred to as 'capillarization' are characterized by

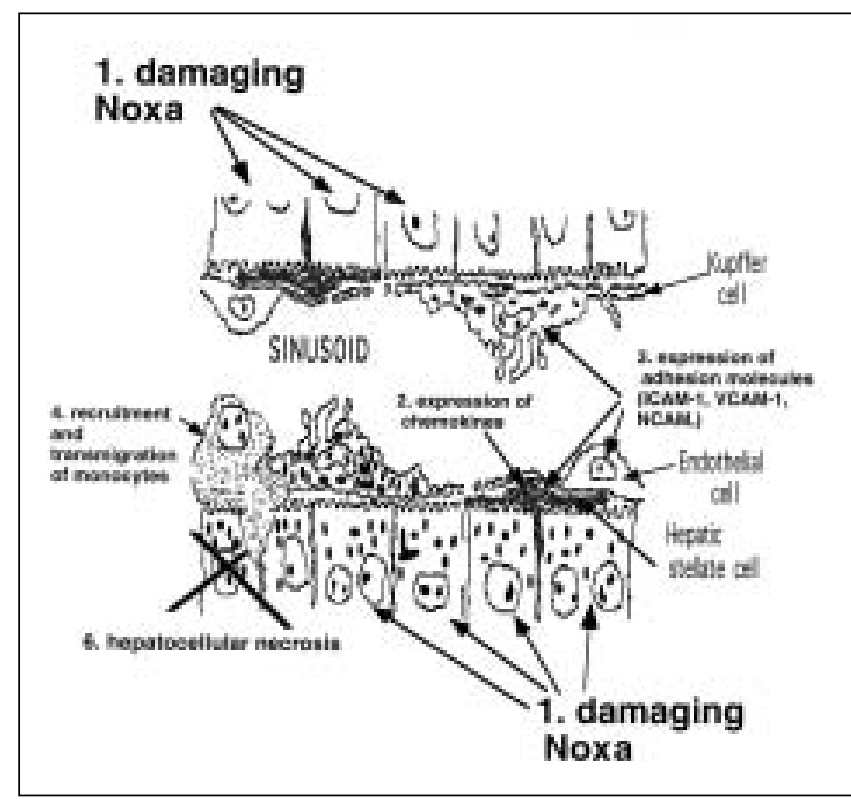

Figure 1) Pathogenesis of liver fibrogenesis. Recruitment of inflammatory cells induced by stressed hepatocyctes followed by hepatocellular death. ICAM-I Intercellular adhesion molecule-1; NCAM Neural cell adhesion molecule; VCAM-1 Vascular cell adhesion molecule-1

a decrease in the size and number of endothelial cell fenestrae, and the development of a basement membrane within the space of Disse $(12,13)$. Endothelial cell defenestration precedes sinusoidal fibrosis. It has been suggested that defenestration may contribute to fibrogenesis by causing a reduction in endothelial cell sieving of lipids and vitamin A in the perisinusoidal cell, leading to a depletion of vitamin A (14). The initial defenestration of endothelial cells before the development of fibrosis appears to be reversible with the removal of the hepatotoxin. However, in the case of persistent damage, matrix proteins, including the basement membrane components collagen type IV, laminin, entactin and fibronectin, increase with the formation of an organized basement membrane-like structure immediately beneath the endothelial cells. There is also accumulation of collagen types I, II, V and VI, tenascin and undulin in the space of Disse $(15,16)$. The increase of interstitial collagens and of laminin is thought to contribute to further endothelial cell defenestration and phenotypic change. 'Capillarization' of the sinusoids hinders the normal exchange between plasma and hepatocytes and is, therefore, a major contributor to the deterioration of liver function that occurs with liver disease. Capillarization takes place in the sinusoids lining the bridge between the portal and the central vein, or between two central veins or two portal tracts (Figure 2).

Progressive deposition of ECM - Scar formation: The persistence of noxious agents leads to a progressive replacement of hepatocytes by connective tissue. Whereas the components of the ECM of the fibrotic liver qualitatively resemble that of normal liver, all components are increased 


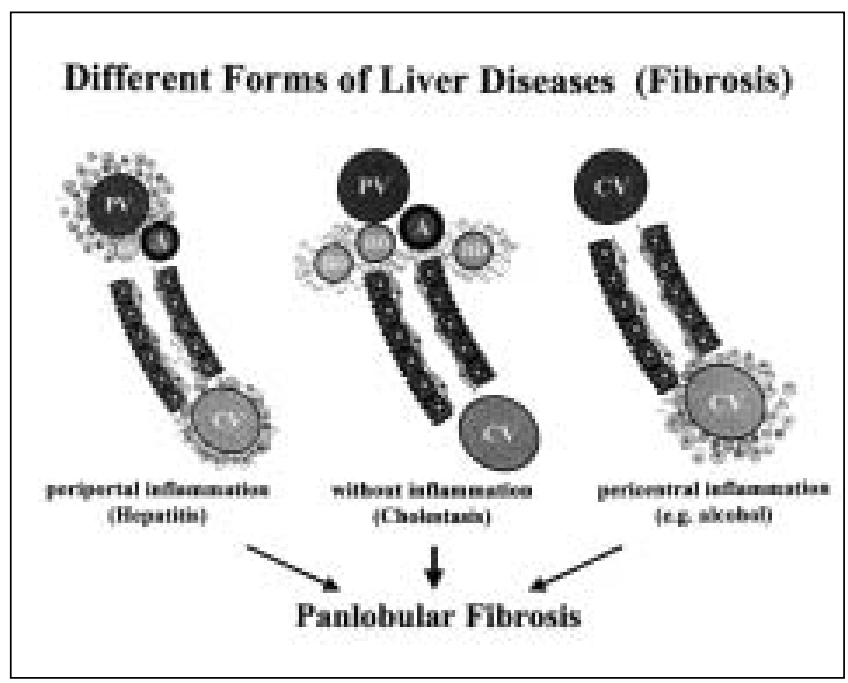

Figure 2) Scar formation

in fibrotic liver with an over-proportional increment of single ECM proteins.

During early liver fibrogenesis, fibronectin and tenascin increase within necroinflammatory areas, early fibrous septa and the outer regions of larger septa. The deposition of fibrinogen/fibrin suggests the involvement of a 'clotting-like process during short term liver injury and liver fibrosis, indicating that fibrin/fibronectin constitutes a 'provisional matrix', which influences attraction and proliferation of inflammatory and matrix-producing cells $(17,18)$. The glycoprotein laminin was found in early septa and the outer regions of larger septa but is of less or no importance in necroinflammatory areas $(19,20)$. In fibrous septa, the presence of entactin, undulin and von Willebrand factor was demonstrated, whereby the von Willebrand factor is closely related to newly formed vessels $(16,21,22)$. SPARC (secreted protein acidic and rich in cystein; osteonectin, BM-40) expression also increases during the course of liver fibrogenesis (23).

In accordance with the scheme of wound healing and scar formation, collagen type III is first increased after liver damage and is finally substituted with collagen type I, the latter constituting $60 \%$ to $70 \%$ of the total collagen in the cirrhotic liver (sixfold increment compared with normal liver). In the case of alcoholic liver disease, however, collagen type III is the major component of the fibrotic septa $(19,24,25)$. Furthermore, collagen type IV, V and VI are also detected in the fibrous septa (19).

Although the amount of matrix in the liver is similar in different forms of liver damage, the distribution of the ECM varies with the site and origin of the injury. For example, in the case of viral hepatitis, there is a periportal inflammation, which is then followed by fibrosis in the periportal zones. On the other hand, ECM deposition during the development of cholestatic fibrosis occurs without inflammation (26). Finally, during alcoholic liver disease, early injury and fibrosis are mainly pericentral. However, during

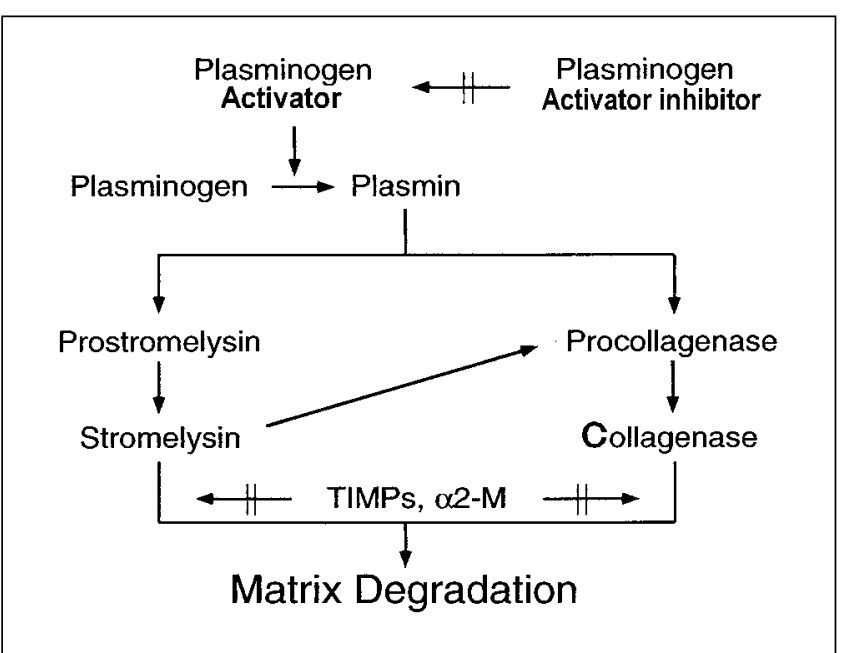

Figure 3) Mechanisms of transforming growth factor-beta-induced accumulation of extracellular matrix through interaction with activated hepatic stellate cells. TIMP Tissue inhibitor of metalloproteinase; a2-M Alpha ${ }_{2}$-macroglobulin

progressive disease, both periportal and pericentral injury lead to panlobular fibrosis (Figure 2).

Matrix degradation: Accumulation of connective tissue reflects an alteration in the balance between synthesis and degradation of ECM. Metalloproteinases (matrix metalloproteinase $[\mathrm{MMP}]$ ) and their specific inhibitors, tissue inhibitor of metalloproteinase (TIMP)-1 and -2 , are believed to play a crucial role in ECM remodelling. In addition to HSCs (27-30), TIMP-1 is expressed in rat hepatocytes in primary culture and regulated by inflammatory cytokines (in particular interleukin-6), illustrating that hepatocytes are involved in ECM protein degradation (31).

Levels and cellular sites of gene expression of two major collagen-degrading enzymes for MMP-1 and MMP-2 in normal and fibrotic human livers as well as in human HSCs were analyzed by Milani et al (32). HSCs expressed both MMP-1 and MMP- 2 mRNA in vitro. The expression of MMPs and TIMPs in all rat liver cell types was recently demonstrated, although the cellular expression levels were markedly different. Gelatinase-B was predominantly expressed by Kupffer cells (KCs), gelatinase A, stromelysins 1 and 2, and collagenase in HSCs (33). TIMP-1 was mainly present in HSCs and TIMP-2 in KCs, while TIMP-3 expression was detectable only in hepatocytes. Furthermore, a cytokine-specific regulation of TIMP/MMP expression was demonstrated, suggesting that the initial matrix breakdown following liver injury might be enhanced by tumour necrosis factor (TNF)- $\alpha$, while the diminished matrix degradation during chronic tissue injury might be due to the activation of transforming growth factor (TGF)- $\beta 1$ through TIMP induction (Figure 3) (33).

\section{CELLS INVOLVED IN LIVER FIBROGENESIS}

At the cellular level, origin of liver fibrogenesis is initiated by the damage of hepatocytes, resulting in a recruitment of inflammatory cells and platelets, and activation of $\mathrm{KCs}$, 


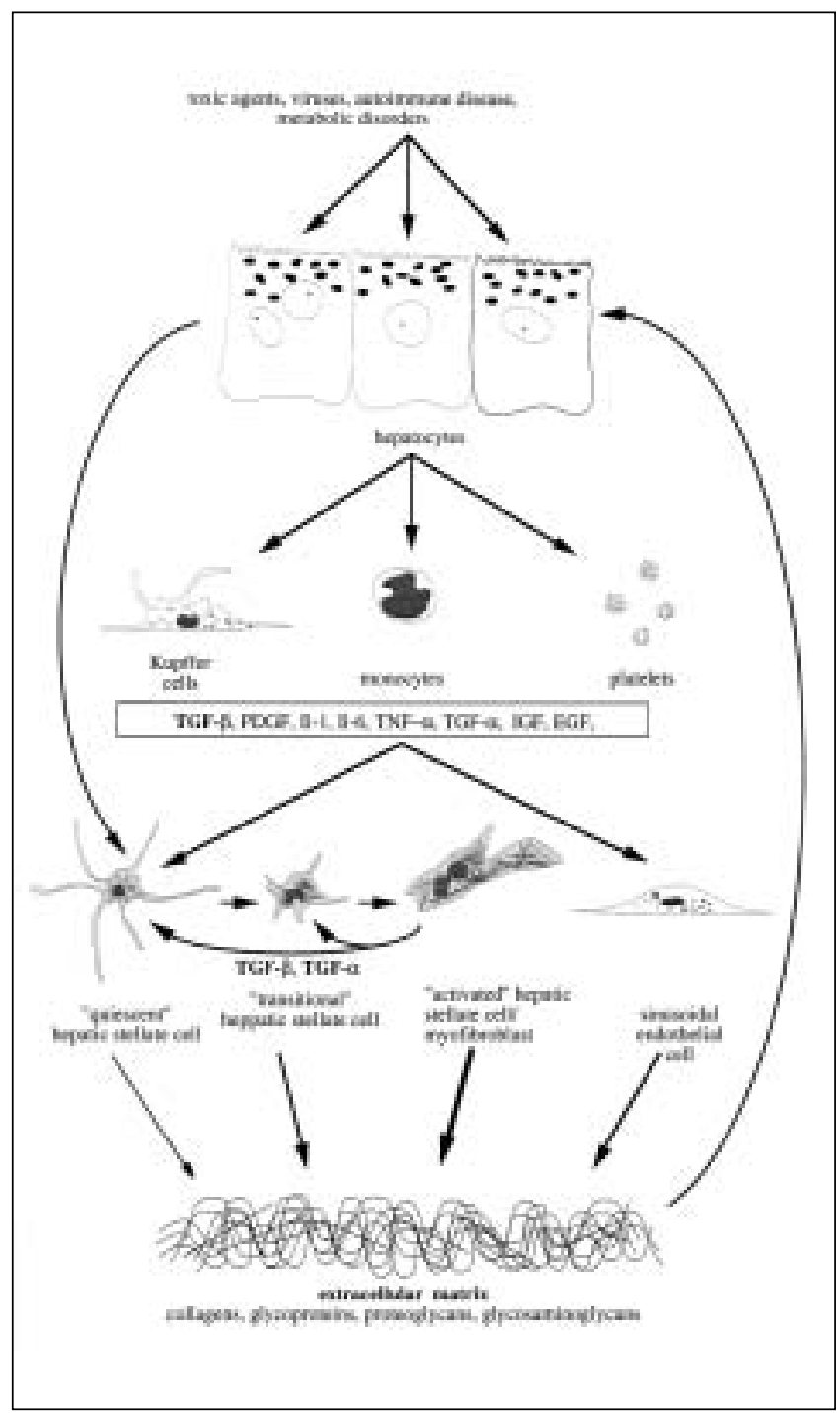

Figure 4) Pathogenesis of liver fibrogenesis. Activation of matrix-producing cells (hepatic stellate cells, myofibroblasts and sinusoidal endothelial cells). EGF Epithelial growth factor; IGF Insulin growth factor; Il Interleukin; PDGF Platelet-derived growth factor; TGF Transforming growth factor; TNF Tumour necrosis factor

with subsequent release of cytokines and growth factors. Whereas it could be shown that sinusoidal endothelial cells (SECs), bile duct epithelial cells, hepatocytes, KCs, fibroblasts and myofibroblasts are involved in fibrogenesis through the formation of ECM, HSCs seem to be the primary target cell for these inflammatory stimuli.

HSCs and myofibroblasts: Interstitial fibroblasts, as well as myofibroblasts, have been shown to be of particular fibrogenic importance in early stages of cholestatic and seruminduced hepatic fibrosis models (26). In this context, however, it must also be mentioned that myofibroblasts are only insufficiently delimited from activated HSCs (34).

The 'activation' of quiescent HSCs is recognized to be one of the most important steps in the development of liver fibrosis. Activation describes the proliferation (?) of HSCs as well as the morphological transformation from vitamin
A-storing 'quiescent' cells, through an intermediate state ('transitional' HSCs), to myofibroblast-like 'activated' HSCs, which represent the major matrix-producing cells during liver fibrogenesis. In vivo initiation of activation of HSCs is caused by the synthesis of cytokines and non-peptide mediators produced by damaged hepatocytes, endothelial cells, fibroblasts, platelets and activated macrophages/KCs. Regarding matrix synthesis in activated HSCs, the growth factors TGF- $\alpha$, TGF- $\beta$ and TNF- $\alpha$ are of particular importance because all of these, especially TGF- $\beta$, upregulate matrix gene expression in these cells (Figure 4) (35-38).

For a long time, the mechanisms that result in the termination of HSC proliferation when tissue repair is concluded were poorly understood. However, it was recently shown that, in vitro and in vivo after acute liver damage, HSCs express CD95 and CD95L in increasing amounts in parallel with activation; furthermore, spontaneous apoptosis has been shown to occur (39). This suggests that HSCs induce a self-activated cell death when their work is no longer needed. However, the fate of activated HSCs during liver injury is still unclear. It has been suggested that HSCs continue to stay alive by a mechanism of self perpetuation. It was recently demonstrated that TGF- $\beta$, the main fibrogenic mediator, as well as TNF- $\alpha$, not only reduces proliferation of activated HSCs, but also inhibits spontaneous and induced apoptosis in vitro (40). This may be a mechanism that allows HSCs to survive and continue matrix production. However, when the damaging insult is withdrawn, the increased number of stellate cells is reduced by apoptosis.

During activation of HSCs, the synthesis of ECM proteins by HSCs increases, and the pattern of the synthesized proteins changes. The ECM proteins produced by quiescent HSCs are typically deposited in basement membranes (laminin, collagen type IV, entactin), whereas activated HSCs synthesize more proteins located in the interstitium, eg, collagen type $1(15,41-43)$.

SECs: Evidence has been published that, in addition to HSCs, SECs are capable of synthesizing ECM proteins, since it has been demonstrated that SECs synthesize collagen types I, II and IV, fibronectin, tenascin, undulin, laminin, entactin, thrombospondin and von Willebrand factor in vivo and in vitro $(13,22,44-48)$. Whereas perlecan is expressed by both SECs and portal endothelial cells, syndecan 1 is produced by SECs and syndecan 3 by portal endothelial cells $(49,50)$. On the mRNA level, differences in matrix proteins expressed were found between SECs isolated from normal liver and SECs isolated from injured liver because SECs from injured liver produce elevated mRNA levels for collagen types I, III, IV, fibronectin and laminin $(13,44)$. Furthermore, it could be demonstrated that SECs respond upon stimulation with TGF- $\beta 1$ with an enhanced synthesis of ECM proteins (Figure 4) (13), which is in accordance with the fact that TGF- $\beta 1$ receptors are expressed by SECs (35). The data suggest that, in addition to HSCs, SECs are also a source of matrix proteins present in the space of Disse. Although HSCs seem to be responsible for 
the synthesis of matrix proteins at later stages of disease, endothelial cells play a role under basal conditions as well as during 'capillarization' of the sinusoids at the beginning of fibrosis.

KCs: Little matrix production has been ascribed to KCs. Macrophage cultures contain small amounts of fibronectin and proteoglycans, and mRNA for collagen types I, III and IV $(47,51,52)$. Furthermore, KCs have been shown to express aggrecan in an in vivo study (53). In mononuclear phagocytes from damaged livers, increased fibronectin synthesis was demonstrated (54). Nevertheless, KCs and inflammatory mononuclear phagocytes are of critical importance for repairing processes as well as for liver fibrogenesis due to their capacity to synthesize a high amount of cytokines, which influence matrix synthesis and degradation by myofibroblast-like cells and other liver cells (Figures 1 and 4) $(55,56)$.

Hepatocytes: Previous reports have claimed that hepatocytes contain collagen types I, III and IV, as well as plasma and cellular fibronectin; laminin; hyaluronic acid; sulphated glycoproteins, especially heparan sulphate, dermatan sulphate, chondroitin sulphate, syndecans and perlecan; and recently also collagen type XVIII (47,51,52,57-62). Caution is required before interpreting matrix synthesis by cultured hepatocytes following the recognition that contaminating HSCs may be responsible for ECM production in hepatocyte cultures (63). Studies of the in vivo incorporation of radiolabelled collagen precursors suggest that hepatocytes play only a minor role in total collagen production in normal liver and during early fibrosis (64).

Bile duct epithelial cells: Bile duct epithelial cells produce procollagen type I, prolylhydroxylase, syndecan 1, syndecan 4, glycipan and heparan sulphate. Beyond this, mRNA for collagen type IV and laminin has been shown in bile duct epithelium $(65,66)$. This could be of great relevance during

\section{REFERENCES}

1. Garcia-Barcin M, Lukomska B, Gawron W, et al. Expression of cell adhesion molecules on liver associated lymphocytes and their ligands on sinusoidal lining cells in patients with benign or malign liver disease. Am J Pathol 1995;146:1406-13.

2. Knittel T, Aurisch S, Neubauer K, Eichhorst S, Ramadori G. Celltype specific expression of neuronal cell adhesion molecule (NCAM) in hepatic Ito-cells: Upregulation during in vitro activation and in hepatic tissue repair. Am J Pathol 1996;149:449-61.

3. Steinhoff G, Behrend M, Schrader B, Duijvestijn A, Wonigeit K. Expression patterns of leukocyte adhesion ligand molecules on human liver endothelia: lack of ELAM - I and CD 62 inducibility on sinusoidal endothelium and distinct distribution of VCAM-1, ICAM-1, ICAM-2, and LFA-1. Am J Pathol 1993;142:481-8.

4. Neubauer K, Eichhorst ST, Wilfling T, Buchenau M, Xia L, Ramadori G. Sinusoidal ICAM-1 upregulation precedes the accumulation of LFA-1 positive cells and tissue necrosis in a model of $\mathrm{CCI}_{4}$-induced acute rat liver injury. Lab Invest 1998;78:185-94.

5. Marra F, Pinzani M. Expression of monocyte chemotactic protein-1 precedes monocyte recruitment in a rat model of acute liver injury, and is modulated by vitamin E. J Invest Med 1999;47:66-75.

6. Maher JJ, Scott MK. Rat hepatic stellate cells produce cytokine induced neutrophil chemoattractant in culture and in vitro. Am J Physiol 1998;275:G847-53.

7. Sprenger H, Gressner A. Induction of neutrophil-attracting chemokines in transforming rat hepatic stellate cells. the development of fibrosis in cholestatic liver diseases.

Therapeutic approaches: The identification of ECM- or MMP- and TIMP-producing cells as well as the characterization of regulatory mechanisms are the basis for therapeutic approaches, which either inhibit fibrogenesis or activate matrix degradation. Such approaches should be taken into consideration if there is no way of eliminating the hepatic noxa (67-69).

According to the pathophysiological concepts, reduced fibrogenesis can be induced by inhibition of fibrogenic mediators using neutralizing antibodies or cytokine-binding proteins; on the other side, neutralization of lipid peroxidation products may also be important. It has been demonstrated that the inhibition of the fibrogenic mediator TGF- $\beta 1$ by neutralizing antibodies or the administration of hepatocyte growth factor decreased fibrogenesis $(70,71)$.

Intending to bind free oxygen radicals, recent studies have successfully employed antioxidants such as vitamin E and polyenylphosphatidylcholine for therapy of fibrogenesis $(72,73)$. In in vitro studies, the activation of HSCs in culture was inhibited by vitamin A treatment. Because vitamin A, however, is potentially toxic, its therapeutic impact may be not relevant.

During later stages of disease, pharmaceuticals should be employed that inhibit the ECM synthesis, change the macromolecule organization of the ECM and stimulate the degradation. So far, substances have been identified that inhibit collagen synthesis, as for example the prolylhydroxylase inhibitor HOE 077, the collagen type I synthase inhibitor halofuginone or pentoxifyllin, which also inhibits proliferation of HSCs $(74,75)$.

Taken together, only results from animal experiments are available, and the published data are often conflicting. Therefore the elimination of the hepatotoxins is so far the sole therapeutic concept available for the treatment of liver fibrogenesis in humans.

Gastroenterology 1997;113:277-85.

8. Sprenger H, Gressner A. Differential expression of monocyte chemotactic protein-1 (MCP-1) in transforming rat hepatic stellate cells. J Hepatol 1999;30:88-94.

9. Marra F, Pinzani M. Increased expression of monocyte chemotactic protein-1 during active hepatic flbrogenesis: correlation with monocyte infiltration. Am J Pathol 1998;152:423-30.

10. Hellerbrand C, Wang S, Tsukamoto H, Brenner D, Rippe R. Expression of intercellular adhesion molecule-1 by activated hepatic stellate cells. Hepatology 1996;24:670-6.

11. Knittel T, Dinter C, Kobold D, et al. Expression and regulation of adhesion molecules by hepatic stellate cells of rat liver. Am J Pathol 1999;154:153-67.

12. Schaffner F, Popper H. Capillarization of the hepatic sinusoids in man. Gastroenterology 1963;44:239-46.

13. Neubauer K, Krüger M, Quondamatteo F, Knittel T, Saile B, Ramadori G. Transforming growth factor-betal stimulates the synthesis of basement membrane proteins laminin, collagen type IV and entactin in rat liver sinusoidal endothelial cells. J Hepatol 1999;31:692-702.

14. Tanikawa K, Noguchi K, Sata M. Ultrastrucutural features of Kupffer cells and sinusoidal endothelial cells in chronic ethanol fed rats. In: Wisse E, Knock D, McCuskey RS, eds. Cells of the Hepatic Sinusoid, vol 3. Rijswijk: Kupffer Cell Foundation, 1991:98-101.

15. Ramadori G, Schwoegler S, Veit $\mathrm{T}$, et al. Tenascin gene expression in 
rat liver and rat liver cells. Virchows Arch B Cell Pathol 1990;60:145-53.

16. Knittel T, Armbrust T, Schwogler S, Schuppan D, Ramadori G. Distribution and cellular origin of undulin in rat liver. Lab Invest 1992;67:779-87.

17. Schuppan D. Structure of the extracellular matrix in normal and fibrotic liver: collagens and glycoproteins. Semin Liver Dis 1990;10:1-10.

I 8. Neubauer K, Knittel T, Armbrust T, Ramadori G. Accumulation of fibrinogen during short term and long term rat liver injury. Gastroenterology 1995;108:1124-35.

19. Ballardini G, Faccani A, Fallani M, et al. Sequential behaviour of extracellular matrix glycoproteins in an experimental model of hepatic fibrosis. Virchows Arch B Cell Pathol Incl Mol Pathol 1985;49:317-24.

20. Inuzuka S, Ueno T, Torimura T, Sata M, Abe H, Tanikawa K. Immunohistochemistry of the hepatic extracellular matrix in acute viral hepatitis. Hepatology 1990;12:249-56.

21. Knittel T, Neubauer K, Armbrust T, Ramadori G. Expression of von Willebrand factor in normal and diseased rat livers and in cultivated liver cells. Hepatology 1995;21:470-6.

22. Schwoegler S, Neubauer K, Knittel T, Chung A, Ramadori G. Entactin gene expression in normal and fibrotic rat liver and in rat liver cells. Lab Invest 1994;70:525-36.

23. Frizell E, Liu SL, Abraham A, et al. Expression of SPARC in normal and fibrotic livers. Hepatology 1995;21:847-54.

24. Seyer JM, Hutcheson ET, Kang AH. Collagen polymorphism in normal and cirrhotic human liver. J Clin Invest 1977;59:241-8.

25. Hahn E, Wick G, Pencev D, Timpl R. Distribution of basement membrane proteins in normal and fibrotic human liver: collagen type IV, laminin and fibronectin. Gut 1980;21:36-71.

26. Tuchweber B, Desmouliere A, Bochaton-Piallat ML, Rubbia-Brandt L, Gabbiani G. Proliferation and phenotypic modulation of portal fibroblasts in the early stages of cholestatic fibrosis in the rat. Lab Invest 1996;74:265-78.

27. Iredale JP, Murphy G, Hempty RM, Friedman SL, Arthur MJ. Human hepatic lipocytes synthesize tissue inhibitor of matrix metalloproteinases-1. Implication for regulation of matrix degradation in liver. J Clin Invest 1992;90:282-7.

28. Benyon RC, Iredale JP, Goddard S, Winwood PJ, Arthur MJ. Expression of tissue inhibitor of metalloproteinases 1 and 2 is increased in fibrotic human liver. Gastroenterology 1996;110:821-31

29. Herbst H, Wege T, Milani S, et al. Tissue inhibitor of metalloproteinase- 1 and -2 RNA expression in rat and human liver fibrosis. Am J Pathol 1997;150:1647-59.

30. Iredale JP, Goddard S, Murphy G, Benyon RC, Arthur MJ. Tissue inhibitor of metalloproteinase-1 and interstitial collagenase expression in autoimmune chronic active hepatitis and activated human hepatic lipocytes. Clin Sci 1995;89:75-81.

31. Roeb E, Graeve L, Hoffmann R, Decker K, Edwards DR, Heinrich PC. Regulation of tissue inhibitor of matrix metalloproteinases- 1 gene expression by cytokines and dexamethason in rat hepatocyte primary cultures. Hepatology 1993;18:1437-42.

32. Milani S, Herbst H, Schuppan D, et al. Differential expression of matrix metalloproteinases-1 and 2 genes in normal and fibrotic human liver. Am J Pathol 1994;144:528-37.

33. Knittel T, Mehde M, Kobold D, Saile B, Dinter C, Ramadori G. Expression patterns of matrix metalloproteinases and their inhibitors in parenchymal and non-parenchymal cells in rat liver: regulation by TNF- $\alpha$ and TGF- $\beta 1$. J Hepatol 1999;30:48-60.

34. Knittel T, Kobold D, Saile B, et al. Rat liver myofibroblasts and hepatic stellate cells: different cell populations of the fibroblast lineage with fibrogenic potential. Gastroenterology 1999;117:1205-21.

35. Rieder H, Armbrust T, Meyer zum Bueschenfelde KH, Ramadori G. Contribution of sinusoidal endothelial liver cells to liver fibrosis: Expression of transforming growth factor-beta- 1 receptors and modulation of plasmin generating enzymes by transforming growth factor- $\beta 1$. Hepatology 1993;18:937-44.

36. Gressner AM, Lofti S, Gressner G, Haltner E, Kropf J. Synergism between hepatocytes and Kupffer cells in the activation of fat storing cells (perisinusoidal lipocytes). J Hepatol 1993;19:117-32.

37. Armbrust T, Nordmann B, Kleissig M, Ramadori G. C1q-synthesis by tissue mononuclear phagocytes from normal and from damaged rat livers: upregulation by dexamethasone and downregulation by interferon gamma and lipopolysaccharide. Hepatology 1997;26:98-106.

38. Matsuoka M, Zhang M, Tsukamoto H. Senzitization of hepatic lipocytes by high fat diet to stimulatory effects of Kupffer cell-derived factors: implication in alcoholic liver fibrogenesis. Hepatology 1990;11:173-82.

39. Saile B, Knittel T, Matthes N, Schott P, Ramadori G. CD95/CD95Lmediated apoptosis of the hepatic stellate cell. A mechanism terminating uncontrolled hepatic stellate cell proliferation during hepatic tissue repair. Am J Pathol 1997;151:1265-72.

40. Saile B, Matthes N, Knittel T, Ramadori G. Transforming growth factor beta and tumor necrosis factor alpha inhibit both apoptosis and proliferation of activated rat hepatic stellate cells. Hepatology 1999;30:196-202.

41. Hautekeete ML, Geerts A. The hepatic stellate (Ito) cell: its role in human liver disease. Virchows Arch 1997;430:195-207.

42. Ramadori G. The stellate cell (Ito-cell, fat-storing cell, lipocyte, perisinusoidal cell) of the liver. New insights into pathophysiology of an intriguing cell. Virchows Arch B Cell Pathol Incl Mol Pathol 1991;61:147-58.

43. Pinzani M. Novel insights into the biology and physiology of the Ito cell. Pharmacol Ther 1995;66:387-412.

44. Maher JJ, McGuire RF. Extracellular matrix gene expression increases preferentially in rat lipocytes and in sinusoidal endothelial cells during hepatic fibrosis in vivo. J Clin Invest 1990;86:1641-8.

45. lrving MG, Roll J, Huang S, Bissell D. Characterization and culture of sinusoidal endothelium from normal rat liver: lipoprotein uptake and collagen phenotype. Gastroenterology 1984;87:1233-47.

46. Rieder H, Ramadori G, Dienes HP, Meyer zum Bueschenfelde KH. Sinusoidal endothelial cells from guinea pig liver synthesize and secrete cellular fibronectin in vitro. Hepatology 1987;7:856-61.

47. Geerts A, Greenwel P, Cunningham M, et al. Identification of connective tissue gene transcripts in freshly isolated parenchymal, endothelial, Kupffer and fat-storing cells by Northern hybridization analysis. J Hepatol 1993;19:134-43.

48. Herbst H, Frey A, Heinrichs O, et al. Heterogeneity of liver cells expressing procollagen types I and IV in vivo. Histochem Cell Biol 1997;107:399-409.

49. Rescan PY, Loreal O, Hassel JR, Yamada Y, Guillouzo A, Clement B. Distribution and origin of the basement membrane component perlecan in rat liver and primary hepatocyte culture. Am J Pathol 1993;142:199-208.

50. Roskams T, Moshage H, de Vos R, Guido D, Yap P, Desmet V. Heparan sulphate proteoglycan expression in normal human liver cells. Hepatology 1995;21:950-8.

51. Rieder H, Birmelin M, Decker K. Synthesis and functions of fibronectin in rat liver cell in vitro. In: Knock DJ, Wisse E, eds. Sinusoidal Liver Cells, vol 1. Leuwen: Elsevier Biomedical Press, 1982:1923-2000.

52. Gressner AM, Haarmann R, Schäfer S, Zerbe O. The role of fat storing cells in matrix proteoglycan and hyaluronate production in relation to Kupffer cell and hepatocytes. In: Wisse E, Knook DL, McCuskey RS, eds. Cells of the Hepatic Sinusoid, vol 2. Rijswijk: Kupffer Cell Foundation, 1988:64-8.

53. Krull NB, Gressner AM. Differential expression of keratan sulphate proteoglycans fibromodulin, lumican and aggrecan in normal and fibrotic rat liver. FEBS Lett 1992;312:4752.

54. Armbrust T, Ramadori G. Mononuclear phagocytes of acutely injured rat liver abundantly synthesize and secrete fibronectin in contrast to Kupffer cells of normal rat liver. Biochem Biophys Res Commun 1995;213:752-8.

55. Shiratori Y, Geerts A, Ichida T, Kawase, Wisse E. Kupffer cells from CC14-induced fibrotic livers stimulate proliferation of fat-storing cells. J Hepatol 1986;3:294-303.

56. Zerbe O, Gressner A. Proliferation of fat-storing cells is stimulated by secretions of Kupffer cells from normal and injured liver. Exp Mol Pathol 1988;49:87-101.

57. Hata R, Ninomiya Y, Nagai Y, Tsukada Y. Biosynthesis of interstitial types of collagen by albumin producing rat liver parenchymal cells (hepatocytes) clones in culture. Biochemistry 1980;19:169-76.

58. Tsutsumi M, Takada A, Takase S, Oshima A. Connective tissue components in cultured parenchymal and non-parenchymal cells of rat liver: Immunohistochemical studies. Lab Invest 1988;58:88-92. 
59. Diegelmann RF, Guzelian PS, Gay R, Gay S. Collagen formation by the hepatocyte in primary monolayer culture and in vivo. Science 1983;219:1343-5.

60. Odenthal M, Neubauer K, Meyer zum Bueschenfelde KH, Ramadori G. Rat hepatocytes in primary culture synthesize and secrete cellular fibronectin. Exp Cell Res 1992;203:289-96.

61. Musso O, Rehn M, Saarela J, et al. Collagen XVIII is localized in sinusoids and basement membrane zones and expressed by hepatocytes and activated stellate cells in fibrotic human liver. Hepatology 1998;28:98-107.

62. Schuppan D, Cramer T, Bauer M, Strefeld T, Hahn EG, Herbst H. Hepatocytes as a source of collagen type XVIII endostatin. Lancet 1998;352:879-80. (Lett)

63. Maher JJ, Bisell DM, Friedman SL, Roll FJ. Collagen measured in primary cultures of normal rat hepatocytes derives from lipocytes within the monolayer. J Clin Invest 1988;82:450-9.

64. Ogata I, Mochida S, Tomiya T, Fujiwara K. Minor contribution of hepatocytes to collagen production in normal and early fibrotic rats. Hepatology 1991;14:361-7.

65. Soroka C, Farquhar M. Characterization of a novel heparan sulfate proteoglycan found in the extracellular matrix of liver sinusoids and basement membranes. J Cell Biol 1991;113:1231-41.

66. Malizia G, Giannuoli G, Caltagirone M, Pisa R, Pagliaro L. Procollagen type I production by hepatocytes: a marker of progressive liver disease? Lancet 1987;ii:1055-7.
67. Schuppan D, Atkinson J, Ruehl M, Riecken EO. Alcohol and liver fibrosis - pathobiochemistry and treament. Z Gastroenterol 1995;33:546-50.

68. Wu J, Danielsson A. Inhibition of hepatic fibrosigenesis: a review of pharmacological candidates. Scand J Gastroenterol 1994:29:385-91.

69 Friedman SL. Molecular mechanisms of hepatic fibrosis and principles of therapy. J Gastroenterol 1997;32:424-30.

70. Tahara M, Matsumoto K, Nukuwa T, Nakamura T. Hepatocyte growth factor leads to recovery from alcohol induced fatty liver in rats. J Clin Invest 1990;103:313-20.

71. Matsumoto K, Nakamura T. HGF: Its organotrophic role and therapeutic potential. Ciba Found Symp 1999;212:198-214.

72. Navder KP, Baraona E, Lieber CS. Polyenylphosphatidylcholine attenuates alcohol-induced fatty liver and hyperlipemia in rats. J Nutr 1997;127:1800-6.

73. Brady LM, Fox ES, Fimmel CJ. Polyenylphosphatidylcholine inhibits PDGF-induced proliferation in rat hepatic stellate cells. Biochem Biophys Res Commun 1998;248:174-9.

74. Pines M, Nagler A. Halofuginone: a novel antlfibrotic therapy. Gen Pharmacol 1998;30:445-50.

75. Lee KS, Cottam HB, Houglum K, Wasson DB, Carson D, Chojkier M. Pentoxifylline blocks hepatic stellate cell activation independently of phosphodiesterase inhibitory activity. Am J Physiol 1997;273:G1094-100. 


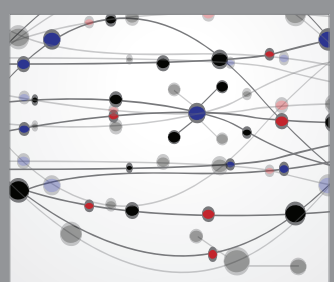

The Scientific World Journal
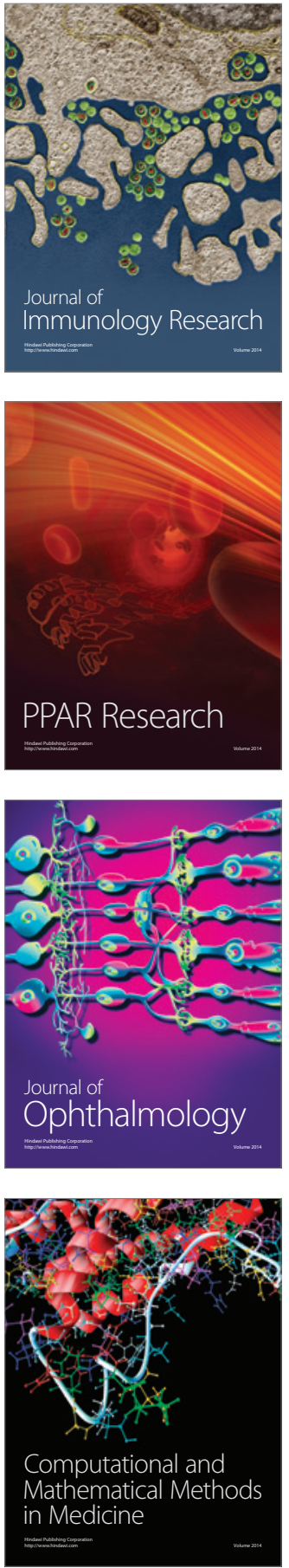

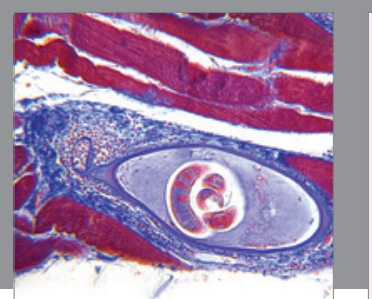

Gastroenterology Research and Practice

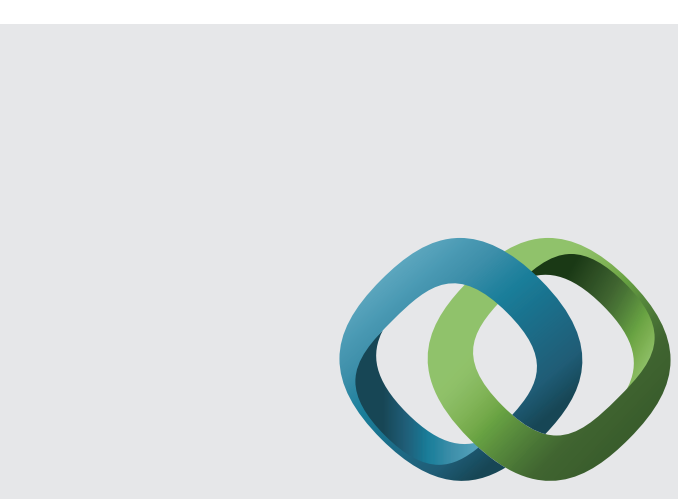

\section{Hindawi}

Submit your manuscripts at

http://www.hindawi.com
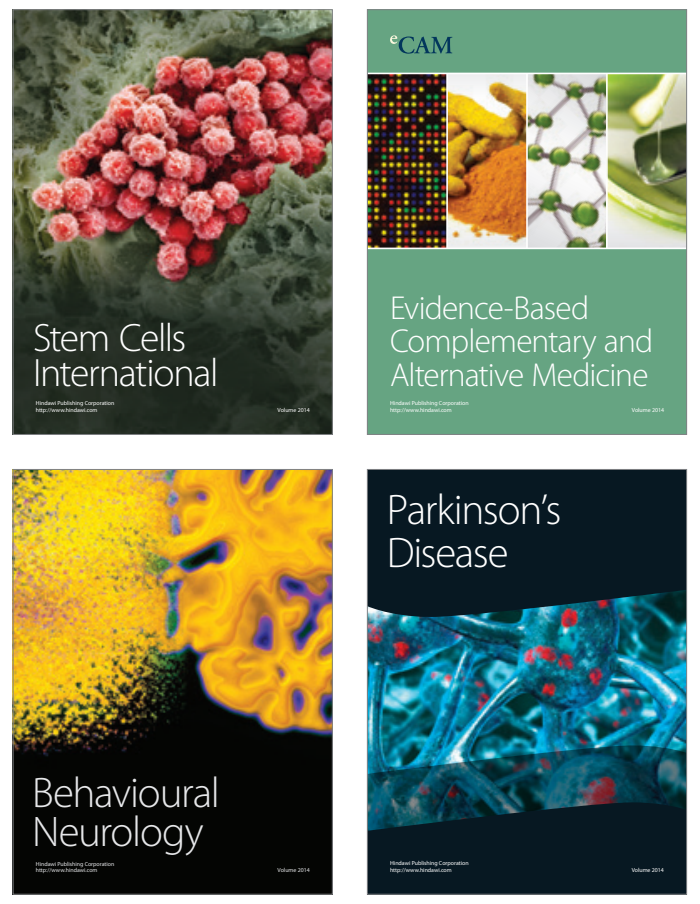
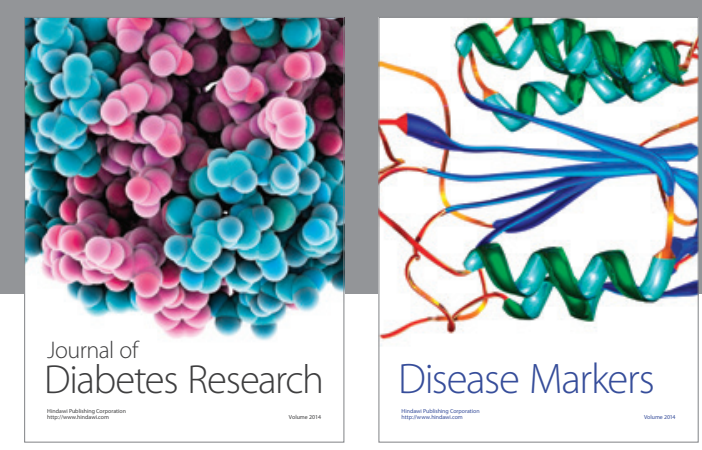

Disease Markers
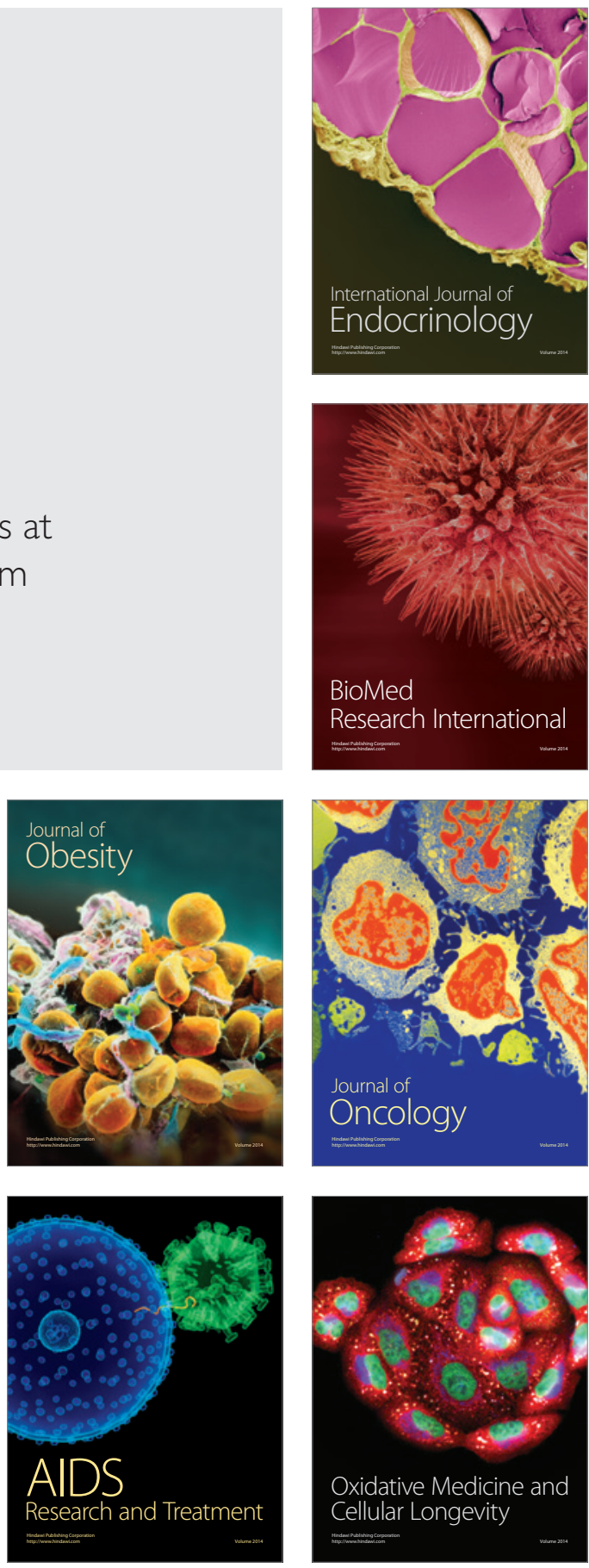